\title{
SHOULDER
}

\section{The Oxford Shoulder Score: Cross-cultural adaptation and translational validation into Afrikaans}

\author{
Kruger $\mathrm{N}^{1}$, Stander $\mathrm{L}^{2}$, Maqungo $\mathrm{S}^{3}$, Roche $\mathrm{S}^{4}$, Held $\mathrm{M}^{5}$ \\ MBChB(UCT), MSc (t) Diag Imaging (OXON), MSc (res) Orth (OXON); Orthopaedic Research Unit, Department of Orthopaedics, University of Cape Town \\ BSc(Hons)(Stel)Anatomy, BSc Anatomy(Stel), BTech(Hons)(CPUT); Division of Anatomy and Histology, Faculty of Medicine and Health Sciences, Stellen- \\ bosch University, Tygerberg, Cape Town \\ MBChB, FC Orth(SA), MMed; Professor and Head: Orthopaedic Trauma Service, Orthopaedic Research Unit, Department of Orthopaedics, University \\ of Cape Town \\ 4 MBChB, FC Orth(SA); Professor and Head: Shoulder and Elbow Unit, Orthopaedic Research Unit, Department of Orthopaedics, University of Cape Town \\ MD, PhD(UCT), FC Orth(SA), Orthopaedic Research Unit, Department of Orthopaedics, University of Cape Town
}

Corresponding author: Dr Neil Kruger, Orthopaedic Research Unit, Department of Orthopaedics, University of Cape Town, H49, Old Main Building, Groote Schuur Hospital, Observatory, Cape Town, 7937; email: neilkruger6@gmail.com; cell: 0027 793782480; tel: 0027214045108

\begin{abstract}
Purpose: The Oxford Shoulder Score (OSS) is a robust and universally utilised shoulder score that has been translated for use in Western and Asian countries. This study aimed to translate, cross-culturally adapt and psychometrically validate the Afrikaans version of the OSS for use in Africa.

Methods: Translation and cross-cultural adaptation was performed in accordance with guidelines in the literature. Onehundred-and-eight consecutive patients with either degenerative or inflammatory pain of the shoulder were prospectively enrolled. Patients were evaluated by completing the Afrikaans OSS, Constant-Murley, quickDASH, and the Subjective Shoulder Value (SSV) scores. Comprehensibility and acceptance, as well as any floor or ceiling effects, were calculated. Reliability was assessed through reproducibility. Internal consistency was assessed using Cronbach's alpha. Validity was determined using a Pearson correlation coefficient between the Afrikaans OSS and the other validated shoulder scores.

Results: Comprehensibility and acceptance were excellent, and no floor or ceiling effects were observed. Reproducibility $(r=0.99)$ and internal consistency (Cronbach's alpha $=0.93)$ were both excellent. Correlation of the Afrikaans OSS with the Constant-Murley and quickDASH was excellent ( $r=0.84 ; r=0.81$ respectively), and very good with the SSV and Visual Analogue Scale (VAS) pain score ( $r=0.73 ; r=0.66)$.
\end{abstract}

Conclusion: The Afrikaans OSS proved understandable, acceptable, reliable and valid. It is an appropriate instrument for use in Afrikaans-speaking patients with shoulder pain from degenerative or inflammatory origin.

Level of evidence: Level 3

Key words: Patient Reported Outcome Measure (PROM); Oxford Shoulder Score (OSS); shoulder pain; Afrikaans; questionnaire; cross-cultural; quality of life; psychometrics; rotator cuff disease

Citation: Kruger N, Stander L, Maqungo S, Roche S, Held M. The Oxford Shoulder Score: Cross-cultural adaptation and translational validation into Afrikaans. SA Orthop J 2018;17(1):17-23. http://dx.doi.org/10.17159/2309-8309/2018/v17n1a2

Editor: Prof Anton Schepers, University of the Witwatersrand

Received: November 2016 Accepted: February 2017 Published: March 2018

Copyright: @ 2018 Kruger N, et al. This is an open-access article distributed under the terms of the Creative Commons Attribution Licence, which permits unrestricted use, distribution and reproduction in any medium, provided the original author and source are credited.

Funding: This study did not require funding.

Conflict of interest: The authors declare they have no conflicts of interest. 


\section{Introduction}

Shoulder pain from inflammatory or arthritic disease is a disabling condition, with an incidence of $7 \%$ in the general population rising to about $20 \%$ in the elderly. ${ }^{1,2}$ Most studies on shoulder pain have been conducted in developed countries, ${ }^{3}$ but the burden of musculoskeletal disease does not escape low-to-middle income countries. ${ }^{4}$ In these regions, manual labour consists commonly of high-risk work for shoulder pathology such as repetitive work, working with hands above shoulder height, carrying heavy loads, and operating vibrating tools. ${ }^{4-7}$

With specific reference to shoulder pain, the Oxford Shoulder Score (OSS) is a joint-specific patient-reported outcome measure (PROM) to assess patient perception about their shoulder pain and its effect on their quality of life. It has been translated into and validated in numerous European and Asian languages, $, 5,6,8-13$ reflecting its robustness and universal acceptability. It is yet to be translated into and validated in any African language.

Afrikaans is the most spoken language in the western half of South Africa, with 50\% of the Western Cape population speaking it as a first language, and the total number speaking it totalling almost seven million people. ${ }^{14,15}$ With increased emphasis on randomised controlled trials to provide adequate answers to clinical questions, ${ }^{16}$ and the difficulty in acquiring sufficient patient numbers without multicentre international collaboration, ${ }^{17}$ the aim of this study was to translate and crossculturally validate the OSS into Afrikaans to enable appropriate assessment of our patient populations' shoulder pain, and increase its universal applicability.

\section{Methods}

The study was conducted in three distinct phases. The first phase involved the translation of the OSS, followed by a pilot study, run to assess comprehension and suitability of the translated questionnaire. Lastly a definitive prospective trial was undertaken.

\section{Translation}

Translation was performed in accordance with guidelines in the literature. ${ }^{16,18,19}$ Due to the wide variety of dialects spoken among the various ethnic groups, emphasis on understanding and simplicity of concept over grammatical correctness was requested.

Three bilingual speakers independently translated the OSS into Afrikaans. Each person had a medical background and at least a university level degree of education. A single translated version was then agreed upon by consensus decision. Three different translators then back translated this version into English. Following this, a final version was agreed upon, again at consensus, which matched the original version of the OSS (Appendix - see end of article). The translated OSS was piloted on ten consecutive bilingual patients presenting to the upper limb outpatient clinic with shoulder pain. Comprehension of 11 of the 12 questions was perfect. One question required adjustment of one word to a more colloquial form to facilitate easier understanding. All patients completed the questionnaire in less than six minutes and none described the test as difficult or onerous.

\section{Validation study}

A total of 108 consecutive patients were prospectively recruited via the upper limb outpatient clinic of a tertiary care hospital in Cape Town, from July to November 2015.
Patients were included if they were over 18 years of age; were able to read, write and speak both English and Afrikaans; and had shoulder pain arising from inflammatory, degenerative or post-traumatic causes. Patients with shoulder pain from instability, as well as literacy and language difficulties, were excluded.

Each patient first completed the translated OSS, followed by the quickDASH ${ }^{20}$ (which had a Visual Analogue Scale [VAS] pain score included), Subjective Shoulder Value (SSV) ${ }^{21}$ and Constant-Murley Shoulder Assessment. ${ }^{22}$ The clinical assessment of the Constant-Murley Score was administered by a single researcher, under the guidance of and following a training session with the head of the Shoulder Unit.

\section{Patient-specific outcome scores}

\section{Oxford Shoulder Score}

The OSS is a shoulder-specific PROM devised for use in patients with degenerative or inflammatory conditions thereof. It elucidates both the degree and frequency of pain, and its impact on shoulder-related activities of daily living (ADLs). There are 12 questions, graded in the original paper on a Likert scale from 1 to 5 , with a range of 60 (worst) to 12 (best) score. ${ }^{2}$ This was later revised to a more intuitive 0 to 4 scale, with a range from 0 (worst) to 48 (best). ${ }^{23}$ It is simple to administer, validated, consistent, ${ }^{24}$ sensitive to clinical changes, and reliable. ${ }^{2,23,25}$

\section{QuilckDASH -11 Score}

The quickDASH score consists of 11 questions, each graded 1 to 5 . For each question one selection is made, representing the score as felt by the patient over the last week. The scores are then summed, and mathematically manipulated to a score out of $100 .{ }^{20}$ This abbreviated version of the more comprehensive DASH score is reliable, valid and responsive to change. ${ }^{26,27}$

A VAS score, rating pain level with activity, but not specifying the duration, was also recorded with the quickDASH. The scale was from 0 (no pain) to 10 (worst pain).

\section{Subjective Shoulder Value}

The Subjective Shoulder Value (SSV) is a patient estimation of the function in their afflicted shoulder, relative to their completely normal shoulder, expressed as a percentage. ${ }^{21}$

\section{Constant-Murley Score}

This shoulder scoring system is a combination of subjective (patient-reported - three questions) and objective (clinicianbased - five measurements) assessment, adding to a total out of 100. Of the subjective questions, one examines the pain severity and two determine the effect on ADLs (maximum 35 points). The objective measurements involve four questions assessing range of shoulder motion (maximum 40 points), and a last question evaluating abduction force as measured in pounds by a spring scale. ${ }^{22}$

\section{Statistical analysis}

\section{Sample size calculation}

An a priori power calculation, setting alpha at 0.05 and the power at $80 \%$, defined a need for at least 44 patients. This assumed a population mean of 24.9 for the OSS (SD 9.0), ${ }^{23}$ a minimal clinically important difference of half the standard deviation, ${ }^{28}$ and a postulate sample mean to be within 2 points of the population mean. Despite an acceptable power with only 
44 patients, most other studies, in accordance with Terwee et al.'s recommendations, ${ }^{25}$ included more than 100 patients when translating and validating the OSS into their native language..$^{5,8-10}$

\section{Comprehensibility, acceptance and time}

Comprehensibility and acceptance were assessed by compliance via the number of questions answered or omitted. No more than two questions may be omitted for the questionnaire to be valid, and if any single question had two or more answers, we adhered to the convention of adopting the worse score for recording. ${ }^{23}$ The time taken for the patient to complete the OSS was recorded.

\section{Floor and ceiling effects}

Floor and ceiling effects were also determined to assess whether there was any bias introduced at the extremes of the scores. ${ }^{19}$ If more than $15 \%$ of the respondents achieve either the highest or lowest score, these effects are present. ${ }^{29}$ This limits content validity, as discrimination is lost at the limits of the scale.

\section{Reliability}

Reliability is a measure of stability ${ }^{8}$ of a test. It consists of a measure of both reproducibility and internal consistency. The American Society for Testing and Materials (ASTM) recommends both a qualitative statement of the test set-up and a quantitative statement of precision, when assessing the reliability of a measurement tool where the accepted reference values are not known or exactingly defined for the population. ${ }^{30,31}$

This precision in questionnaires involves test-retest reproducibility. It was measured by contacting the first 40 patients telephonically between 24 and 48 hours of their consult, to again complete the Afrikaans OSS. A Pearson correlation coefficient ( $r$ ) was used to determine the correlation between these overall test scores. Pearson correlation coefficients may range from -1 (inverse correlation) to 1 (perfect correlation), with values nearing 0 indicating very poor correlation. ${ }^{9,10}$ Further, a Bland Altman plot was calculated to determine the test-retest score consistency relative to the overall mean, across the range of scores. ${ }^{32}$

Internal consistency was determined by calculating Cronbach's alpha. It defines the correlation between all the items within a scale. ${ }^{8}$ Values may range from 0 to 1 , with 0.90-0.95 optimal for clinical application. ${ }^{33}$ Values above 0.95 indicate items are too similar and may be redundant.

\section{Validity}

Validity is a qualitative characteristic that may be described according to face, content, criterion and construct. ${ }^{34}$ Validity of face exists in that the OSS is ostensibly a questionnaire developed to assess patients' perceptions about their shoulder problems. Content validity was established in the original derivation of the OSS through exploratory interviews with patients', without 'imposing clinical assumptions' and ensuring complete understanding prior to questionnaire finalisation. $^{2}$

Criterion validity cannot truly be determined as there is no universally accepted benchmark PROM for shoulder pain. Validity of construct was assessed by calculating the Pearson correlation between the Afrikaans OSS and the quickDASH, the VAS pain score, the SSV and the Constant-Murley score. The correlation was interpreted as poor, fair, moderate, very good and excellent when $r=|0.00-0.20|, r=|0.21-0.40|$, $r=|0.41-0.60|, r=|0.61-0.80|$ and $r=|0.80-1.00|$, respectively. ${ }^{35}$

\section{Ethics statement}

The institutional Human Research Ethics Council gave approval for the study (HREC reference number 457/2014) and it was conducted in accordance with principles in the declaration of Helsinki (2013). Each patient gave written, informed consent prior to being enrolled.

\section{Results}

\section{Translation}

No major discrepancies were noted between translators in either the forward or backward translation of the OSS. Consensus agreement was reached easily.

\section{Patient and questionnaire characteristics}

All 108 patients who met the inclusion criteria participated and completed the questionnaires. Demographic data and pathology were recorded and are outlined in Table I.

Thirty-nine patients were pending planned surgery, 40 patients post-surgery (not within six weeks post-operatively) and 29 patients were being managed conservatively with no scheduled surgery.

Table I: Demographic data and diagnosis for the study population

\begin{tabular}{|l|c|}
\hline Patients (n) & 108 \\
\hline Mean age - years ( \pm SD) & $55(13)$ \\
\hline Age range - years & $18-84$ \\
\hline Male:female & $49: 59$ \\
\hline Right - Left handed & $105-3$ \\
\hline Right - Left shoulder & $69-39$ \\
\hline Dominant shoulder & 70 \\
\hline Diagnoses $(\%)$ & $n(\%)$ \\
\hline Impingement syndrome with rotator cuff tear & $27(25)$ \\
\hline Impingement syndrome without rotator cuff tear & $17(15.7)$ \\
\hline Primary or secondary OA (glenohumeral or & $33(30.6)$ \\
\hline acromioclavicular) & $13(12)$ \\
\hline Adhesive capsulitis & $3(2.8)$ \\
\hline Calcified deposits in rotator cuff & $15(13.9)$ \\
\hline Other diagnoses & $3(2.8)$ \\
\hline Proximal humerus fracture or non-union & $3(2.8)$ \\
\hline Chronic elbow dislocation with shoulder pain & $2(1.9)$ \\
\hline Acute R/C tear and clavicle fracture & $2(1.9)$ \\
\hline Traumatic suprascapular nerve palsy & $1(0.9)$ \\
\hline ACJ dislocation with pain & $1(0.9)$ \\
\hline Tuberculosis of the shoulder & $3(2.8)$ \\
\hline No diagnosis & \\
\hline
\end{tabular}

Table II: Mean \pm SD and ranges for the scores of all the outcomes measures used

\begin{tabular}{|l|c|c|}
\hline \multicolumn{2}{c}{} & \multicolumn{2}{c|}{ Scores } \\
\hline & Mean \pm SD & Range \\
\hline OSS & $18.03 \pm 11.99$ & $0-48$ \\
\hline quickDASH & $65.00 \pm 23.85$ & $0-100$ \\
\hline quickDASH pain VAS & $7.03 \pm 2.39$ & $0-10$ \\
\hline Constant-Murley & $35.26 \pm 21.48$ & $0-96$ \\
\hline SSV (\%) & $41.29 \pm 23.34$ & $2-95$ \\
\hline
\end{tabular}




\section{Comprehensibility, acceptance and time}

No patients reported any difficulty with comprehension. Acceptance was excellent with all patients answering all the questions for the OSS, and only one patient omitting one question for the quickDASH. The mean time (min:sec) to complete the OSS was 4:09 (standard deviation $[S D] \pm 1: 12$ ). Overall absolute values, mean scores and the ranges are given in Table II.

\section{Floor and ceiling effects}

In the OSS dataset, the lowest possible score is 0 and the highest possible score is 48 . Seven respondents achieved the lowest and only one achieved the highest, totalling $7.4 \%$ of all respondents. No floor or ceiling effects were thus present.

\section{Reliability}

The test-retest reproducibility for the 40 patients was very high $(r=0.99)$. The mean difference between the questionnaires was 0.2 points $(95 \% \mathrm{Cl}-0.31$ to 0.43$)$. The internal consistency was also high (Cronbach's alpha=0.93). Single question elimination did not drop the value significantly, with all items correlating (item total correlation $\geq 0.65$ ) (Table III).

Table III: Mean scores and SDs for each question of the Afrikaans OSS, along with each item total correlation and measure of internal consistency

\begin{tabular}{|c|c|c|c|}
\hline Question & Mean score ( \pm SD) & $\begin{array}{c}\text { Item total } \\
\text { correlation }\end{array}$ & $\begin{array}{c}\text { Cronbach's alpha } \\
\text { (one item removed) }\end{array}$ \\
\hline 1 & $1.036 \pm 0.976$ & 0.678 & 0.924 \\
\hline 2 & $1.772 \pm 1.359$ & 0.777 & 0.920 \\
\hline 3 & $2.455 \pm 1.418$ & 0.700 & 0.924 \\
\hline 4 & $2.200 \pm 1.543$ & 0.770 & 0.921 \\
\hline 5 & $1.682 \pm 1.433$ & 0.771 & 0.921 \\
\hline 6 & $1.818 \pm 1.546$ & 0.676 & 0.926 \\
\hline 7 & $1.364 \pm 1.393$ & 0.793 & 0.919 \\
\hline 8 & $1.255 \pm 1.112$ & 0.760 & 0.921 \\
\hline 9 & $1.200 \pm 1.387$ & 0.800 & 0.919 \\
\hline 10 & $1.536 \pm 1.488$ & 0.851 & 0.916 \\
\hline 11 & $1.091 \pm 1.130$ & 0.784 & 0.920 \\
\hline
\end{tabular}

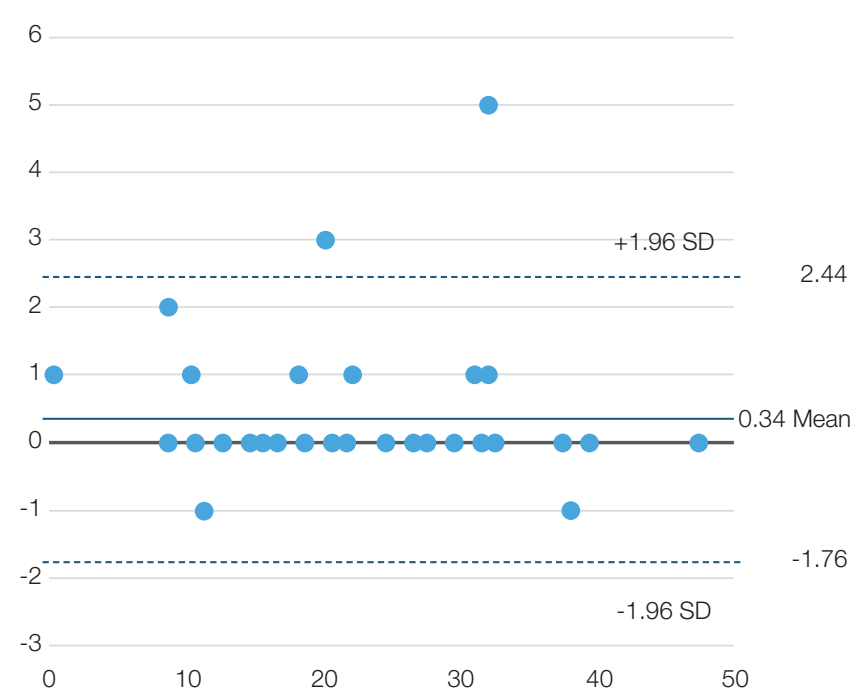

Figure 1. A Bland Altman plot of the differences between the 40 test-retest scores, plotted against the overall mean, across the range of scores achieved
A Bland Altman plot was calculated to indicate the differences between the test-retest scores, as plotted against the overall mean and across the range of scores (Figure 1).

\section{Validity}

Pearson correlation coefficients calculated between the Afrikaans OSS, the Constant-Murley, and the quickDASH were excellent ( $r=0.84$ and 0.81 respectively), and very good for the SSV and the VAS pain score ( 0.73 and 0.66 respectively).

\section{Discussion}

Afrikaans was originally derived from Dutch and is now the first language for approximately seven million people in Southern Africa. ${ }^{15}$ It is a diverse language with multiple dialects and expressions within each dialect, which creates the potential for misunderstanding of questions. This was borne out in our study in the pilot phase, with one question requiring revision of a word 'kruideniersware' meaning 'groceries', to the more colloquial and direct translation of 'huishoudelike inkopies', meaning 'household shopping'. This was rectified for the definitive study, and the results indicate excellent acceptance and understanding, for all patients answered all questions, skipping none. This overall response rate of $100 \%$ was similarly high in comparison to other studies. ${ }^{8-12}$

The mean age of 55 years was approximately the same as that reported for other OSS translation study populations. . $^{8-12}$ There was a slight female preponderance in our study (male:female, 49:59), which was similar to the Turkish ${ }^{11}$ and Chinese ${ }^{12}$ findings. The Dutch ${ }^{5}$ and German ${ }^{8}$ population had approximately equal numbers, with the Italian ${ }^{9}$ and Korean ${ }^{10}$ population having a strong male prevalence. This probably reflects the heterogeneity of shoulder pain from inflammatory or degenerative disease, without a specific sex-associated risk. ${ }^{36,37}$

The mean time taken to complete the OSS (4 min $9 \mathrm{sec}$ ) was slightly longer than in other translations..$^{8-10,12}$ This may reflect the patient population that we serve, for although the inclusion criteria mandated that patients were bilingual in both Afrikaans and English, many have only had access to a basic education possibly resulting in more time to read and complete the questionnaire.

The psychometric properties of the Afrikaans OSS were excellent across all measurements and compared favourably with other validation studies. The test-retest reproducibility was very high ( $r=0.99)$, and the internal consistency was excellent (Cronbach's alpha=0.93), indicating the translated OSS is reliable (Table $M$ ).

By correlating the translated OSS with the Constant-Murley, the quickDASH, the SSV and a VAS pain score, construct validity was determined. All the comparative outcome scores are reliable and widely accepted outcome scores, and correlations between each were either 'very good' or 'excellent', demonstrating good construct validity. The Bland Altman plot of the differences against their means indicated no systematic bias across the range of scores.

The English (data from original paper), German, Italian, Dutch and Korean translations used the older OSS scoring system, while the Chinese and Turkish have adopted the newer, more intuitive scoring system. Absolute values for the scores give an indication of the severity of the patient's perception of their shoulder problem. With simple mathematical conversion, the standardised scores for comparison are given in Table $\mathrm{V}$.

The mean score for the Afrikaans patients is at least 4.6 points below the mean of the lowest scoring population group compared. This is equal to a minimal clinically important difference for the OSS. ${ }^{23}$ Reasons for this difference are likely to be due to access and our patient population. Low-income populations generally have inferior access to healthcare services. 
Table IV: Overall mean values and standard deviations of the OSS for different translation studies ${ }^{2,5,8-12}$

\begin{tabular}{|c|c|c|c|c|c|c|c|c|}
\hline & $\begin{array}{c}\text { Afrikaans } \\
(n=108)\end{array}$ & $\begin{array}{l}\text { Chinese } \\
(n=121)\end{array}$ & $\begin{array}{l}\text { English } \\
(n=111)\end{array}$ & $\begin{array}{c}\text { Dutch } \\
(n=103)\end{array}$ & $\begin{array}{l}\text { German } \\
(n=102)\end{array}$ & $\begin{array}{c}\text { Italian } \\
(n=140)\end{array}$ & $\begin{array}{l}\text { Turkish } \\
(n=84)\end{array}$ & $\begin{array}{l}\text { Korean } \\
(n=105)\end{array}$ \\
\hline OSS (mean \& SD) & $18.03 \pm 11.99$ & Not stated & 36.3 & $32.5 \pm 9.5$ & $27.34 \pm 10.42$ & $36.05 \pm 13.95$ & $22.58 \pm 9.88$ & $25.6 \pm 7.3$ \\
\hline \multicolumn{9}{|l|}{ Reliability } \\
\hline Cronbach's alpha & 0.93 & 0.92 & $0.89-0.92$ & 0.92 & 0.94 & 0.95 & 0.92 & 0.91 \\
\hline $\begin{array}{l}\text { ICC (95\% Cl)/Pearson's } \\
\text { correlation coefficient }\end{array}$ & 0.99 & $\begin{array}{c}0.97 \\
(0.94-0.98\end{array}$ & $\mathrm{N} / \mathrm{A}$ & 0.98 & 0.98 & 0.97 & 0.99 & $\begin{array}{c}0.95 \\
(0.91-0.98)\end{array}$ \\
\hline \multicolumn{9}{|l|}{ Construct validity } \\
\hline Constant-Murley & 0.84 & 0.66 & 0.74 & 0.64 & 0.60 & 0.73 & N/A & $0.3<r<0.6$ \\
\hline quickDASH/DASH & 0.81 & $\mathrm{~N} / \mathrm{A}$ & N/A & $\mathrm{N} / \mathrm{A}$ & N/A & $\mathrm{N} / \mathrm{A}$ & $\mathrm{N} / \mathrm{A}$ & $>0.6$ \\
\hline VAS (pain activity) & 0.66 & 0.70 & N/A & N/A & N/A & N/A & N/A & $0.34-0.45$ \\
\hline
\end{tabular}

Table V: Standardised mean scores for the OSS for each language (range 0-48)

\begin{tabular}{|c|c|c|c|c|c|c|c|c|}
\hline & $\begin{array}{c}\text { Afrikaans } \\
(n=108)\end{array}$ & $\begin{array}{l}\text { Chinese } \\
(n=121)\end{array}$ & $\begin{array}{l}\text { English } \\
(n=111)\end{array}$ & $\begin{array}{c}\text { Dutch } \\
(n=103)\end{array}$ & $\begin{array}{l}\text { German } \\
(n=102)\end{array}$ & $\begin{array}{c}\text { Italian } \\
(n=140)\end{array}$ & $\begin{array}{l}\text { Turkish } \\
(n=84)\end{array}$ & $\begin{array}{l}\text { Korean } \\
(n=105)\end{array}$ \\
\hline OSS (mean) & 18.0 & Not stated & 23.7 & 27.5 & 32.7 & 24.0 & 22.6 & 34.4 \\
\hline
\end{tabular}

Patients often only seek help when it is direly needed due to prohibitive transport costs and long waiting times. This may result in perceived and 'real' differences in their shoulder pain, both from patient desperation for assistance with their shoulder and disease progression.

There are some limitations that merit discussion. Our patient cohort is only from a single centre. Although our drainage area is broad and encompasses a wide spectrum of Afrikaans dialects, it will not have included them all. Secondly, unlike many other studies that translated the OSS into their native languages, ,5,8,9,11,12 we chose not to use a generalised health assessment questionnaire when assessing construct validity. Although shoulder-specific pathology may not necessarily have direct impact on overall patient function and wellness, ${ }^{5,10}$ this would not reflect in our study. Lastly, we did not include a measure of sensitivity to change within the questionnaire, which would have aided assessment of responsiveness.

\section{Conclusion}

The Oxford Shoulder Score has been translated, cross-culturally adapted and validated into Afrikaans in this study. The questionnaire was easily comprehended and completed by all patients. Measures of stability and validity were robust in statistical analysis, with excellent internal consistency and construct validity in comparison to other shoulder outcome scores.

\section{Acknowledgments}

The authors wish to thank Karin Wiese, Francois Meyer, Toni Kriel, Narette Botha, Jani Ferreira and Theodi Albrecht for their assistance with the forward and back translation of the questionnaire.

\section{Compliance with ethical standards}

Ethical approval: The Human Research Ethics Committee (HREC) of the University of Cape Town approved the study prior to its implementation: HREC number 457/2014. A copy thereof is available from the corresponding author if required. All procedures performed in this study were in accordance with the ethical standards of the 1964 Helsinki declaration and its later amendments.

Informed consent: Informed consent was obtained from all individual participants included in the study. 


\section{Appendix}

\section{Afrikaans Oxford Shoulder Score questionnaire}

\section{PROBLEME MET U SKOUER}

Merk slegs een blokkie vir elke vraag $(\boldsymbol{}$

1. Gedurende die afgelope 4 weke... Hoe sal u die ergste pyn van u skouer beskryf?

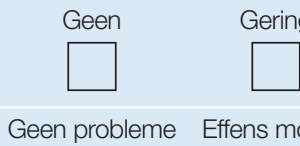

Geen probleme Effens moeilik

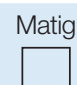

Moeilik

Het $u$ enige probleme gehad om u self klere uit/aan to trek weens u skouer?

3. Gedurende die afgelope 4 weke..

Het $u$ enige probleme gehad om in en uit motors te klim, of van publieke

vervoer te gebruik weens u skouer?

4. Gedurende die afgelope 4 weke...

Was dit vir u moontlik om 'n mes en vurk gelyktydig te gebruik?

5. Gedurende die afgelope 4 weke...

Kon u die huishoudelike inkopies op u eie gaan koop?

6. Gedurende die afgelope 4 weke..

Kon u 'n skinkbord met ' $n$ bord kos daarop deur 'n kamer dra?

7. Gedurende die afgelope 4 weke...

Was dit moontlik om u hare te kam/borsel met die seer arm?

8. Gedurende die afgelope 4 weke...

Hoe sal u die pyn wat u gewoonlik in u skouer ervaar het, beskryf?

9. Gedurende die afgelope 4 weke..

Was dit moontlik vir $u$ om u klere in die kas op te hang met die seer skouer/arm?

10. Gedurende die afgelope 4 weke...

Was dit vir u moontlik om onder albei arms te was en af te droog?

11. Gedurende die afgelope 4 weke...

Tot watter mate het $u$ skouer pyn/ongemak met $u$ daaglikse werk (insluitend tuiswerk) u ingekort?

12. Gedurende die afgelope 4 weke... Pla u skouerpyn u snags as u slaap?

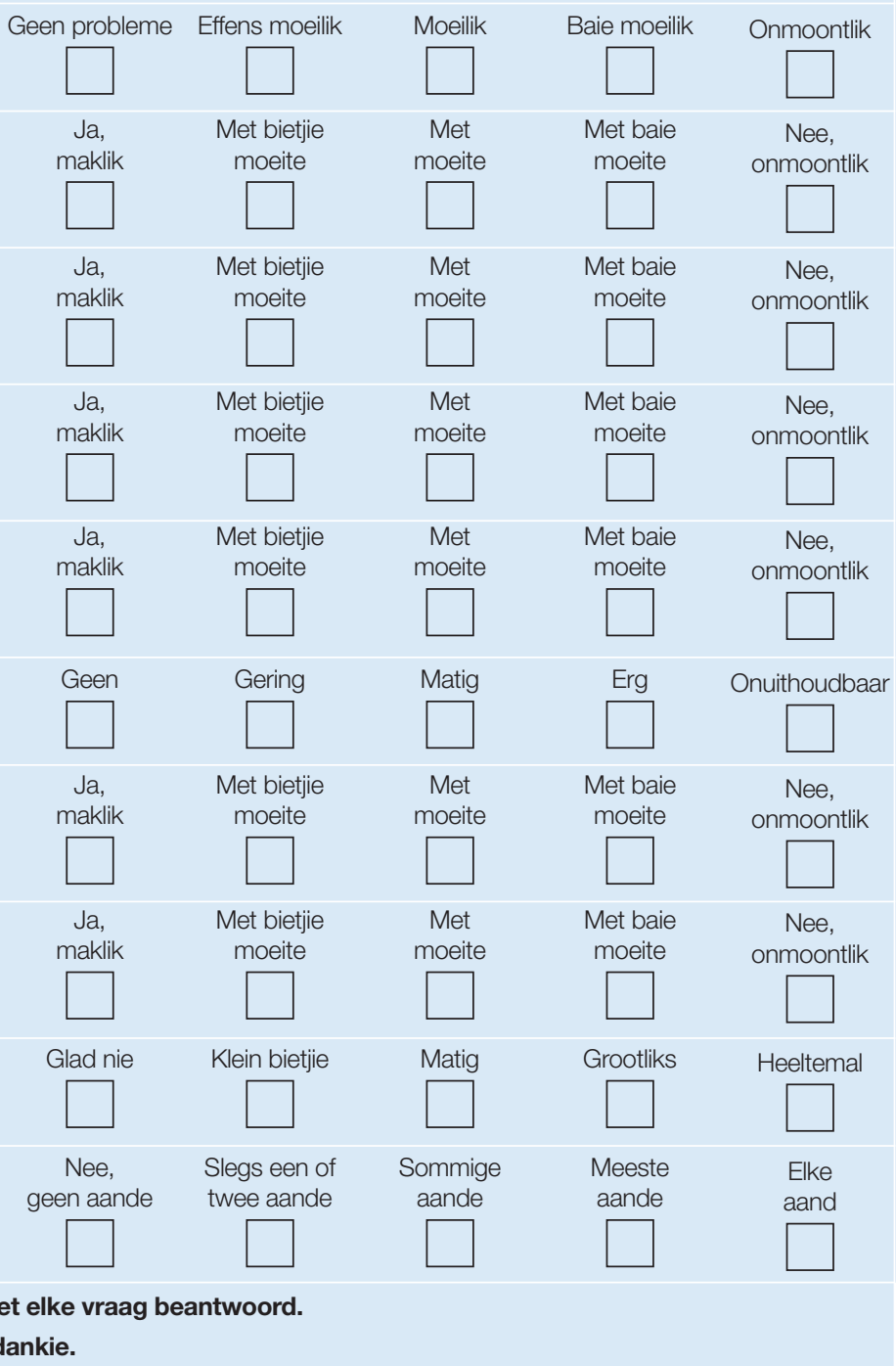

Baie dankie.

\section{References}

1. Chard MD, Hazleman R, Hazleman BL, King RH, Reiss BB. Shoulder disorders in the elderly: a community survey. Arthritis and Rheumatism, 1991;34(6):766-69.

2. Dawson J, Fitzpatrick R, Carr A. Questionnaire on the perceptions of patients about shoulder surgery. British Journal of Bone and Joint Surgery, 1996;78(4):593-600

3. Fejer R, Ruhe A. What is the prevalence of musculoskeletal problems in the elderly population in developed countries? A systematic critical literature review. Chiropractic and Manual Therapies, 2012;20(1):31-83.

4. Naidoo S, Kromhout H, London L, Naidoo RN, Burdorf A Musculoskeletal pain in women working in small-scale agriculture in South Africa. American Journal of Industrial Medicine, 2009;52(3):202-209.

5. Berendes T, Pilot P, Willems J, Verburg H, te Slaa R. Validation of the Dutch version of the Oxford Shoulder Score. Journal of Shoulder and Elbow Surgery, 2010;19(6):829-36.
6. Frich LH, Noergaard PM, Brorson S. Validation of the Danish version of Oxford Shoulder Score. Daishn Medical Bulletin, 2011;58(11):A4335.

7. Cote P, van der Velde G, Cassidy JD, Carroll LJ, Hogg-Johnson S, Holm LW, Carragee EJ, Haldeman S, Nordin M, Hurwitz EL, Guzman J, Peloso PM. The burden and determinants of neck pain in workers: results of the Bone and Joint Decade 2000-2010 Task Force on Neck Pain and Its Associated Disorders. Spine (Phila Pa 1976), 2008;33(4 Suppl):S60-74.

8. Huber W, Hofstaetter JG, Hanslik-Schnabel B, Posch M, Wurnig C. The German version of the Oxford Shoulder Score-crosscultural adaptation and validation. Archives of Orthopaedic and Trauma Surgery, 2004;124(8), 531-36, doi:10.1007/s00402-0040716-z.

9. Murena L, Vulcano E, D'Angelo F, Monti M, Cherubino P. Italian cross-cultural adaptation and validation of the Oxford Shoulder Score. Journal of Shoulder and Elbow Surgery, 2010;19(3): 335-41. 
10. Roh YH, Noh JH, Kim W, Oh JH, Gong HS, Baek GH. Crosscultural adaptation and validation of the Korean version of the Oxford shoulder score. Archives of Orthopaedic and Trauma Surgery, 2012;132(1):93-99.

11. Tugay U, Tugay N, Gelecek N, Ozkan, M. (2011). Oxford Shoulder Score: cross-cultural adaptation and validation of the Turkish version. Archives of Orthopaedic and Trauma Surgery, 131(5), 687-94.

12. Xu X, Wang F, Wang X, Wei X, Wang Z. Chinese cross-cultural adaptation and validation of the Oxford shoulder score. Health and Quality of Life Outcomes, 2015;13(1):193.

13. Ekeberg OM, Bautz-Holter E, Tveita EK, Keller A, Juel NG, Brox $\mathrm{JI}$. Agreement, reliability and validity in 3 shoulder questionnaires in patients with rotator cuff disease. BMC Musculoskeletal Disorders, 2008;9:68.

14. Morris LD, Grimmer-Somers KA, Louw QA, Sullivan MJ. Crosscultural adaptation and validation of the South African Pain Catastrophizing Scale (SA-PCS) among patients with fibromyalgia. Health and Quality of Life Outcomes, 2012;10:137-50.

15. Census 2011: Census in brief (2011). Statistics South Africa. http://www.statssa.gov.za/census/census_2011/census_ products/Census_2011_Census_in_brief.pdf. Accessed 22 May 2016.

16. Guillemin F, Bombardier C, Beaton D. Cross-cultural adaptation of health-related quality of life measures: literature review and proposed guidelines. Journal of Clinical Epidemiology, 1993;46(12):1417-32.

17. Beaton DE, Bombardier C, Guillemin F, Ferraz MB. Guidelines for the process of cross-cultural adaptation of self-report measures. Spine (Phila Pa 1976), 2000;25(24):3186-91.

18. Lohr KN, Aaronson NK, Alonso J, Burnam MA, Patrick DL, Perrin EB, Roberts JS. Evaluating quality-of-life and health status instruments: development of scientific review criteria. Clinical Therapeutics, 1996;18(5):979-92.

19. Mokkink LB, Terwee CB, Patrick DL, Alonso J, Stratford PW, Knol $\mathrm{DL}$, Bouter LM, de Vet HC. The COSMIN checklist for assessing the methodological quality of studies on measurement properties of health status measurement instruments: an international Delphi study. Quality of Life Research, 2010;19(4):539-49.

20. Beaton DE, Wright JG, Katz JN, Group UEC. Development of the QuickDASH: comparison of three item-reduction approaches. American Journal of Bone and Joint Surgery, 2005;87(5):1038-46.

21. Gillbart MK, Gerber C. Comparison of the subjective shoulder value and the Constant score. Journal of Shoulder and Elbow Surgery, 2007; 16(6):717-21.

22. Constant $\mathrm{CR}$, Murley AH. A clinical method of functional assessment of the shoulder. Clinical Orthopaedics and Related Research 1987;214:160-64.

23. Dawson J, Rogers K, Fitzpatrick R, Carr A. The Oxford shoulder score revisited. Archives of Orthopaedic and Trauma Surgery, 2009;129(1):119-23.

24. Dawson J, Hill G, Fitzpatrick R, Carr A. The benefits of using patientbased methods of assessment. Medium-term results of an observational study of shoulder surgery. British Journal of Bone and Joint Surgery, 2001;83(6):877-82.

25. Terwee CB, Bot SD, de Boer MR, van der Windt DA, Knol DL, Dekker $J$, Bouter LM, de Vet HC. Quality criteria were proposed for measurement properties of health status questionnaires. Journal of Clinical Epidemiology,2007;60(1):34-42.

26. Kennedy CA, Beaton DE, Smith P, Van Eerd D, Tang K, Inrig T, Hogg-Johnson S, Linton D, Couban R. Measurement properties of the QuickDASH (disabilities of the arm, shoulder and hand) outcome measure and cross-cultural adaptations of the QuickDASH: a systematic review. Quality of Life Research, 2013;22(9):2509-47.

27. Polson K, Reid D, McNair PJ, Larmer P. Responsiveness, minimal importance difference and minimal detectable change scores of the shortened disability arm shoulder hand (QuickDASH) questionnaire. Manual Therapy, 2010;15(4):404-407.

28. Norman GR, Sloan JA, Wyrwich KW. Interpretation of changes in health-related quality of life: the remarkable universality of half a standard deviation. Medical Care, 2003;41(5):582-92.

29. McHorney CA, Tarlov AR. Individual-patient monitoring in clinical practice: are available health status surveys adequate? Quality of Life Research, 1995;4(4):293-307.

30. Langlois J, Hamadouche M. Current recommendations for assessing the reliability of a measurement tool: a survival guide for orthopaedic surgeons. Bone and Joint Journal, 2016;98-B(2):166-72.
31. Authors not listed. American Society for Testing and Materials (ASTM): standard practice for use of the terms precision and bias in ASTM test methods. 2013. West Conshohocken: ASTM International.

32. Bland JM, Altman DG. Statistical methods for assessing agreement between two methods of clinical measurement. Lancet, 1986;1(8476):307-310.

33. Bland JM, Altman DG. Cronbach's alpha. British Medical Journal, 1997;314(7080):572.

34. McGovern DPB, Valori RM, Summerskill WSM, Levi M. Key topics in evidence-based medicine (Key Topics Series). 2001. Oxford: BIOS Scientific Publishers Ltd.

35. Feise RJ, Michael Menke J. Functional rating index: a new valid and reliable instrument to measure the magnitude of clinical change in spinal conditions. Spine (Phila Pa 1976), 2001;26(1): 78-86; discussion 87

36. Oh JH, Chung SW, Oh CH, Kim SH, Park SJ, Kim KW, Park JH, Lee SB, Lee JJ. The prevalence of shoulder osteoarthritis in the elderly Korean population: association with risk factors and function. Journal of Shoulder and Elbow Surgery, 2011;20(5): 756-63.

37. Yamamoto A, Takagishi K, Osawa T, Yanagawa T, Nakajima D, Shitara H, Kobayashi T. Prevalence and risk factors of a rotator cuff tear in the general population. Journal of Shoulder and Elbow Surgery, 2010;19(1):116-20. 